\title{
Engaging in Literacy: Latino Families Speak Up
}

\author{
Wendy Gonzales ${ }^{1, *}$, Giselle Núñez ${ }^{1}$, Maria De La Luz Soria ${ }^{1} \&$ Marie Tejero Hughes ${ }^{1}$ \\ ${ }^{1}$ Department of Special Education, University of Illinois at Chicago, USA \\ *Corresponding author: College of Education, 1040 W Harrison Street, Chicago, IL 60607, \\ USA.E-mail:wmarti6@uic.edu
}

Received: April 10, 2018 Accepted: May 2, 2018 Published: June 10, 2018

doi:10.5296/ije.v10i2.12984 URL: http://dx.doi.org/10.5296/ije.v10i2.12984

\begin{abstract}
Family engagement has long been evidenced to contribute to successful educational outcomes. In this qualitative study, we examined the language and literacy perspectives of Latino families of young children. A total of 17 participants who each represented a Latino family from a large urban city participated in focus group interviews. Interviews were analyzed using qualitative methodology. The major themes that emerged from the conversations related to how families define literacy, what literacy looks like in their home, the messages schools give families about literacy, and literacy activities parents would like for schools to promote.
\end{abstract}

Keywords: family engagement, literacy, language, Latino parents 


\section{Introduction}

The United States has seen a significant change in the make-up of its population during the past 30 years. One of the largest shifts has been in the racial/ethnic composition of the population, including a significant growth in the Latino population, which is predicted to increase to 119 million by 2060 (Colby \& Ortman, 2015). This demographic shift is especially apparent in schools, where not only are the students more culturally diverse, but over 5 million students are also English Learners (EL) with approximately 76\% speaking Spanish as their native language (Fast Facts, 2014). As schools become more diverse, it is important that educators collaborate with families and find ways to integrate their experiences to overcome any barriers between the home and schools that cultural and linguistic differences may pose.

Family engagement has long been evidenced to contribute to successful educational outcomes (Poza, Brooks, \& Valdés 2014), decrease dropouts (Epstein \& Sheldon, 2002), and to develop early literacy skills (Davis et. al, 2015; Sheridan, Knoche, Kupzyk, Edwards \& Marvin, 2011). Researchers have also noted that parental role construction, or parent's beliefs about what they are supposed to do in relation to their child's education and the patterns of behavior that follow those beliefs, impacts how and when parents will engage with their child (Hoover-Dempsey \& Sandler, 2005). Yet, it has been argued that family engagement differs among cultural groups. For instance, although most Latinos believe that literacy is important (Davis et. al, 2015), they tend to demonstrate different patterns of engagement with schools than families of White children and are traditionally more involved in the home than at school (Rodriguez, Blatz, \& Elbaum, 2013). As schools become more diverse, it is important that educators collaborate with families and find ways to integrate their beliefs and experiences to overcome any barriers between the home and schools that cultural and linguistic differences may pose.

\section{Literature Review}

An important component of family engagement that impacts school success is families' engagement in language and literacy with their children, which can be characterized as book reading, storytelling, singing songs, discussing letters/numbers, doing arts and crafts, and playing games (Marcella et al., 2014). It also includes activities such as providing educational toys and implementing literacy strategies (Larrotta \& Yamamura, 2011). These early learning opportunities at home play a role in children's language and literacy outcomes (Marcella, Howes, \& Fuligni, 2014) and can increase overall intellectual development (Billings, 2009). Even when English is not the language of the interaction, home activities in the child's native language has shown to support the development of native language skills which can later transfer to English (Baird, Kibler, \& Palacios, 2015).

Although it is important to focus on how family activities at home can impact their child's academic success, parental language and literacy activities tend to be drawn from academic frameworks based on middle income White families, such as the cultural resources that are in 
one's home (i.e. the number of books available) (Durand, 2010). Thus, schools have been less than effective in engaging Latino families in schools (O'Donnell \& Kirkner, 2014). This is especially true when the families do not speak the language or are recent immigrants (Rodriguez et al, 2013). When working with a family, various aspects of their culture, for example family values, should be considered to understand academic and social impacts (Ortiz \& Ordoñez, 2005).

Typically, Latino families contribute to language and literacy development within their daily life routines and activities (O'Donnell \& Kirkner, 2014). This draws on the "funds of knowledge" theory in that it reaffirms practices within the home (Moll \& Gonzalez, 2004). As a theory, "funds of knowledge" asserts that children come from homes that are culturally and cognitively rich, and that these home experiences provide the prior knowledge necessary for students to be successful in school. By participating in language and literacy events at home with families in their native language, families are helping to strengthen the literacy foundation of their children (Durand, 2010).

Given that Latino families are usually more involved in their child's education at home then in schools, teachers may not be aware of how families are providing educational supports (Quezada, Diaz, \& Sanchez, 2003). Therefore, it is important to both understand and value home language and literacy practices that Latino families are already engaged in, since it can help schools provide more meaningful family participation activities. Thus, the purpose of this study was to explore Latino families' perceptions and experiences regarding language and literacy activities they engage in at home.

\section{Methodology}

\subsection{Participants}

Families of young children who attended educational programs (e.g., Head Start) at a community center where invited to take part in the study. Families who accessed the services at the center were of a Latino ethnic background (95\%), from low income households, and Spanish was their primary language (63\%). Seventeen individuals (13 mothers, 2 fathers, and 2 relatives), each representing a different Latino family, agreed to participate. All the participants indicated that Spanish was their preferred language.

\subsection{Focus Group Interview}

Focus groups are used in qualitative studies to uncover the perceptions and needs about a topic from representatives of a specific group of people (Bragg, 2000; Vaughn, Schumm, \& Sinagub, 1996). Focus groups have also been used to empower low-income and minority ethnic groups (Rabbie, 2004), and can offer some preliminary explorations of this population's attitudes on a specific topic (Huer \& Saenz, 2003). As a research instrument, the use of focus groups allow researchers to learn about the participants when there is little background information provided, examines sensitive issues within the population, and explores their experiences and viewpoints while interacting with one another (Dishald \& 
Latif, 2013); however, a limitation is that focus groups may provide a setting for a homogenous group of participants to answer the researcher's question which may not take into account all viewpoints (Dishald \& Latif, 2013; Huer \& Saenz, 2003).

Focus group interviews were conducted by native Spanish speaking researchers with four to eight participants in attendance at each interview. No identifying information were obtained due to possible sensitive circumstances in families' living situation. The researchers had developed a level of trust with the community by presenting parent workshops at the center. The focus groups consisted of four main questions: 1. What does literacy mean to you?; 2 . What are language and literacy activities that you do at home as a family or individually with your child?; 3. What suggestions do your children's teachers or school offer you to help develop your children's language and literacy at home?; and 4. What suggestions do you have about how teachers and schools can support families with regard to developing their child's language and literacy?

Researchers encouraged all to respond to the questions asked and to engage with the ideas that others brought up. The researchers posed a question and open it up to family members for discussion. Those who did not speak up were encouraged directly to participate. The moderators always ended by offering participants a chance to contribute any additional comments they felt they did not have an opportunity to share. Families were thanked for their participation by having them participate in a raffle for a gift card at the end of each focus group interview.

\subsection{Data Analysis}

Data from the interview transcripts were gathered and coded using qualitative methodology. The interviews were transcribed into Spanish and coding was completed in Spanish to avoid any misunderstandings. Following guidelines suggested by Miles and colleagues (2014), three flows of analysis were applied for summarizing the data in the interviews. The first flow of analysis involved the researchers independently summarizing the interviews, identifying key themes, and then meeting to discuss findings. During the second flow of analysis, data summaries were developed for each theme, summaries were presented to the research team, and negotiation of finding using the group mind process were completed (Denzin \& Lincoln, 2011). During the final flow of analysis, the research team drew final conclusions, verified findings, and summarized to reflect the four major themes that emerged in the analysis.

\section{Findings}

The major themes that emerged from the conversations related to: families understanding of literacy, the literacy activities they engaged in at home, how schools communicate to families about literacy engagement, and what families wished schools would do or tell them to support families' literacy development. Within each theme, specific suggestions and ideas emerged that provided valuable insights into the families' perspectives, which can be used by educators to develop stronger collaborations focused on their needs and expectations. 
In general, most families' understanding of literacy focused on describing activities that developed reading and writing skills with families defining literacy as reading skills and comprehension. However, a few families believed it was more encompassing including the ability to communicate effectively. Other families expressed the idea that literacy could also include looking at pictures in the books without necessarily reading the words off the page. Many families also defined literacy as the development of oral vocabulary. As one parent noted when discussing what was literacy, "Literacy for me are the activities that we can do at home with our children. The materials do not matter, as teachers have demonstrated that we can use materials commonly found at home without spending a lot of money, with simply pasta, cereal, color cardboard one can also do literacy activities." Families were also aware how important it was to combine other life skills to increase literacy skills. For example, a parent reported, "when you are going to cook, in the recipe you are using literacy because you are asking about measurements. Even though you are using math, you are also using literacy. You are asking-reading what it says-the instructions."

Of the language and literacy activities that families engaged in at home, storybook reading was the most common and for many of them reading was part of their bedtime routine. Families also talked about reading other types of materials, such as when this mom reads with her son while they make pancakes, "I tell my son when we make pancakes 'Read the directions there, tell me how many to put' and I make him do it." Other activities families did at home included playing games such as memory, "I Spy", and Loteria, which is a Mexican game like bingo. Aside from having fun with their children, families also incorporated play to help their child learn academic skills. As this parent explained that when she played with her children she would ask them questions to help them describe the color of the cars or what the dolls were doing: "When he's playing with his trains I ask him, what are the colors? How does the car look? And with my daughter, well, she has her Barbie house, so we talk about the different things that house has, for example in the kitchen, what's in the kitchen? The dishes, and in the bathroom?" Many families also described how they incorporated different vocabulary into their everyday conversations with their children. These enriched conversations occurred during mundane activities such as grocery shopping. As this parent noted, 'we would go to the supermarket and I would tell him 'That's an apple, it's red.' I would always ask him, "what is this?" Likewise, another parent had her child sort the food they buy at the grocery store as they put it away and practice counting the different items, "For example, the tomato, to separate it from the tomatillo, I take advantage to tell them, especially my daughter, 'how many tomatoes are there?' She's peeling the tomatoes and counting them and then she puts the tomatillo somewhere else. Then my son goes to the refrigerator and I tell him, for example, after I bought some yogurt, I say 'go to the refrigerator and arrange the yogurt'."

Families also talked about the advice schools provided them related to language and literacy which primarily included giving them suggestions such as to include technology and skill-based activities. The most common activities teachers recommended were the use of free English based websites. Many teachers also told the families the literacy skills the children needed to work on and advice on how to implement them at home. For example, one parent 
noted that her daughter was having difficulty with summarizing and explaining a story so "They told me to read her a story and then afterwards have her explain what the story was about. I read her stories and afterwards, I say, 'let's see, tell me what the story was about, you tell me' and she is getting a little bit better." Another parent indicated that the teachers provide monthly workshops and taught the parents the concepts the children are learning at school so that parents learn the rigor with which the children are learning: "They bring workshops to educate the parents, for example, they bring reading and they show us the words that make them up or synonyms or cause and effect."

Finally, families recognized that they were responsible for their children learning at home, and it was not the school's sole responsibility to teach their children everything. As this parent noted, "a parent needs to be responsible and sit with them and reinforce as well. I think that it is important to reinforce on both sides, but I think that it is more important with parents, to be more responsible ...". However, families did offer a variety of activities that both schools and teachers can offer to increase awareness of language and literacy activities that families can participate in. For example, this parent stated, "I think that it would be a good idea to create a literacy club for parents." Many suggested that specific workshops be offered to the school community, "I would like that schools do these types of meetings because many times schools just tell you "your child needs you to help them more."”

\section{Discussion}

In this qualitative study, we examined the language and literacy perspectives of Latino families of young children. Previous research has shown that Latino families felt that it is important to be involved in their child's education (Drummond \& Stipek, 2004); however, research has been ineffective in showing how they demonstrate this involvement. As with previous work (Davis et al., 2015), it was clear that the Latino families in the study were involved in a great deal of language and literacy activities which they engaged in Spanish at their homes. Families discussed how they participated in book reading, games, and conversations with their children. Although families did mention attending school events and having regular meetings with the teachers, the bulk of their conversations concentrated on things done as a family outside of school. Likewise, the language and literacy events that many families engaged in were not what is considered typical in school activities, as they were daily activities, and not necessarily planned teaching activities. This is echoed in a study by Poza and colleagues (2014) that found that families mentioned forms of involvement that they deem valuable, but that were not always considered as such by teachers or schools. At the same time, some of the activities the families engaged in approached more traditional school like activities. It is important that schools acknowledge all these activities conducted in Spanish as valuable and expand the home-based practices into school-based practices, in order to increase parent participation within the school (Saracho, 2007).

Teachers may not be aware of how Latino families who may not speak English can provide language and literacy support at home (Quezada et al., 2003). Thus, schools should consider taking up some of the family suggestions such as the use of book clubs and family run parent 
workshops to connect more regularly with families. Through these avenues, schools can create stronger links with the home. Family input regarding language and literacy is very important, as this takes into consideration the family's "funds of knowledge". It is through these relationships and dialogue between professional and families that the role of how language and literacy can be reinforced at home can begin. The building of parent confidence can continue as families are included in their child's learning and have a deeper understanding that the activities that they engage with their children at home have value and indeed reinforce academic skills.

As we know, family support of a child's educational life is vital to academic success, especially in the first years of schooling (Durand, 2010). However, when families are from culturally or linguistically diverse backgrounds, schools may not be effective in engaging their participation due to cultural differences in beliefs of literacy and school participation (O’Donnell \& Kirkner, 2014). This disconnect between home and school may negatively impact academic outcomes for students. This does not mean, however, that Latino families do not engage in the promotion of language and literacy.

\subsection{Limitations}

Although engaging in these conversations with families was insightful, it should be noted that the study had several limitations including a small participant pool which can impact the generalizability of the findings. In addition, the findings are only limited to the experience of the Latino families that were interviewed, and not of all the parents that were in the community center. However, the families that did participate appeared to be representative of the type of families that utilize the services at the center.

\section{Declaration of Conflicting Interest}

The authors declare that there is no conflict of interest.

\section{References}

Baird, A. S., Kibler, A., \& Palacios, N (2015). "Yo te estoy ayudando; estoy aprendiendo tambien/ I am helping you; I am learning too:" A bilingual family's community of practice during home literacy events. Journal of Early Childhood Literacy, 15, 147-176. https://doi.org/10.1177/1468798414551949

Billings, E. S. (2009). Prescriptions to read: Early literacy promotion outside the classroom. Literacy, Teaching and Learning, 13(1/2), 81.

Bragg, D. (2000). Capturing the richness of palliative education outcomes through the use of focus groups. Journal of Palliative Medicine, 3(2), 204-207. https://doi.org/10.1089/10966210050085287 


\section{Al Macrothink}

International Journal of Education ISSN 1948-5476 2018, Vol. 10, No. 2

Colby, S. L., \& Ortman, J. M. (2015). Projections of the size and composition of the U.S. population 2014 to 2060: Population estimates and projections. Current Population Reports, 25-1143.

Retrieved from: https://census.gov/content/dam/Census/library/publications/2015/demo/p25-1143.pdf

Davis, H. S., Gonzalez, J. E., Pollard-Durodola, S., Saenz, L. M., Soares, D. A., Resendez, N., Zhu, L., \& Hagan-Burke, S. (2015). Home literacy beliefs and practices among low-income Latino families. Early Child Development and Care, 27, 1-21.

Denzin, N. K., \& Lincoln, Y. S. (2011). The Sage handbook of qualitative research. Newbury Park, CA: Sage.

Dishald, R. M., \& Latif, M. I. (2013). Focus group interview as a tool for qualitative research: An analysis. Pakistan Journal of Social Science, 33(1), 191-198.

Durand, T. (2010). Latina mothers' school preparation activities and their relation to children's literacy skills. Journal of Latinos and Education, 9, 207-222. https://doi.org/10.1080/15348431003761182

Drummond, K. V., \& Stipek, D. (2004). Low-income parents' beliefs about their role in children's academic learning. The Elementary School Journal, 104, 197-213. https://doi.org/10.1086/499749

Epstein, J. L., \& Sheldon, S. B. (2002). Present and accounted for: Improving student attendance through family and community involvement. The Journal of Educational Research, 95, 308-318. https://doi.org/10.1080/00220670209596604

Fast Facts. (2014). Fast Facts. Retrieved from http://nces.ed.gov/fastfacts/display.asp?id=96

Hoover-Dempsey, K. V., \& Sandler, H. M. (1997). Why do parents become involved in their children's education? Review of Educational Research, 67(1), 3-42. https://doi.org/10.3102/00346543067001003

Huer, M. B., \& Saenz, T. I. (2003). Challenges and strategies for conducting survey and focus group research with culturally diverse groups. American Journal of Speech Language Pathology, 12, 209-220. https://doi.org/10.1044/1058-0360(2003/067)

Larrotta, C., \& Yamamura, E. (2011). A community wealth approach to Latina/o family involvement: The promise of family literacy. Adult Basic Education and Literacy Journal, 5(2), 74-83.

Marcella, J., Howes, C., \& Fuligni, A. S. (2013). Exploring cumulative risk and family literacy practices in low-income Latino families. Early Education and Development, 25, 36-55. https://doi.org/10.1080/10409289.2013.780504 
Miles, M. B., Huberman, M. A., \& Saldaña, J. (2014). Qualitative data analysis: A methods sourcebook. Thousand Oaks, CA: Sage.

Moll, L., \& Gonzalez, N. (2004). Engaging life: A funds-of-knowledge approach to multicultural education. Inj. Banks \& C. Banks (Eds.), Handbook of research on multicultural education (pp. 699-715).

O'Donnell, J., \& Kirkner, S.L. (2014). The impact of a collaborative family involvement program on Latino families and children's educational performance. School Community Journal, 24(1), 211-234.

Ortiz, R., \& Ordoñez, R. (2005). Leyendo Juntos (reading together): New directions for Latino parents' early Literacy development. International Reading Association, 59, 110-121. https://doi.org/10.1598/RT.59.2.1

Poza, L., Brooks, M. D., \& Valdés, G. (2014). Entre familia: Immigrant parents' strategies for involvement in children's schooling. School Community Journal, 24(1), 119-148.

Quezada, R. L., Diaz, D. M., \& Sanchez, M. (2003). Involving Latino Parents. Leadership, 33(1), 32-34, 38.

Rabiee, F. (2004). Focus-group interview and data analysis. Proceedings of the Nutrition Society 63, 655-660. https://doi.org/10.1079/PNS2004399

Rodriguez, R., Blatz, E., \& Elbaum, B. (2013). Strategies to involve families of Latino students with disabilities: When parent initiative is not enough. Intervention in School and Clinic, 49, 263-270. https://doi.org/10.1177/1053451213513956

Saracho, O. N. (2007). Hispanic families as facilitators of their children's literacy development. Journal of Hispanic Higher Education, 6, 103-117. https://doi.org/10.1177/1538192706299009

Sheridan, S. M., Knoche, L. L., Kupzyk, K. A., Edwards, C. P., \& Marvin, C. A. (2011). A randomized trial examining the effects of parent engagement on early language and literacy: The Getting Ready intervention. Journal of School Psychology, 49, 361-383. https://doi.org/10.1016/j.jsp.2011.03.001

Vaughn, S. R., Schumm, J. S., \& Singub, J. M. (1996). Focus group interviews in education and psychology. Thousand Oaks, CA: Sage. https://doi.org/10.4135/9781452243641 


\section{Macrothink}

International Journal of Education

ISSN 1948-5476

\section{Copyright Disclaimer}

Copyright for this article is retained by the author(s), with first publication rights granted to the journal.

This is an open-access article distributed under the terms and conditions of the Creative Commons Attribution license (http://creativecommons.org/licenses/by/3.0/). 